\title{
Article \\ Acute Effects of Particulate Matter on All-Cause Mortality in Urban, Rural, and Suburban Areas, Italy
}

\author{
Matteo Renzi ${ }^{1, *}$, Stefano Marchetti ${ }^{2}$, Francesca de' Donato ${ }^{1}$, Marilena Pappagallo ${ }^{2} \oplus$, Matteo Scortichini ${ }^{1}{ }^{1}$, \\ Marina Davoli ${ }^{1}$, Luisa Frova ${ }^{2}$, Paola Michelozzi ${ }^{1}$ and Massimo Stafoggia ${ }^{1}$ \\ 1 Department of Epidemiology, Lazio Region Health Service/ASL Roma 1, 00147 Rome, Italy; \\ f.dedonato@deplazio.it (F.d.D.); m.scortichini@deplazio.it (M.S.); m.davoli@deplazio.it (M.D.); \\ p.michelozzi@deplazio.it (P.M.); m.stafoggia@deplazio.it (M.S.) \\ 2 Division of Integrated Systems for Health, Social Assistance and Welfare, Italian National Institute of \\ Statistics, 00184 Rome, Italy; stmarche@istat.it (S.M.); pappagal@istat.it (M.P.); frova@istat.it (L.F.) \\ * Correspondence: m.renzi@deplazio.it
}

\section{check for} updates

Citation: Renzi, M.; Marchetti, S.; de' Donato, F.; Pappagallo, M.;

Scortichini, M.; Davoli, M.; Frova, L.; Michelozzi, P.; Stafoggia, M. Acute Effects of Particulate Matter on All-Cause Mortality in Urban, Rural, and Suburban Areas, Italy. Int. J. Environ. Res. Public Health 2021, 18, 12895. https://doi.org/10.3390/ ijerph182412895

Academic Editor: Paul B. Tchounwou

Received: 20 October 2021

Accepted: 1 December 2021

Published: 7 December 2021

Publisher's Note: MDPI stays neutral with regard to jurisdictional claims in published maps and institutional affiliations.

Copyright: (c) 2021 by the authors. Licensee MDPI, Basel, Switzerland. This article is an open access article distributed under the terms and conditions of the Creative Commons Attribution (CC BY) license (https:// creativecommons.org/licenses/by/ $4.0 /)$.

\begin{abstract}
Background: Short-term exposure to particulate matter (PM) has been related to mortality worldwide. Most evidence comes from studies conducted in major cities, while little is known on the effects of low concentrations of PM and in less urbanized areas. We aim to investigate the relationship between PM and all-cause mortality at national level in Italy. Methods: Daily numbers of all-cause mortality were collected for all 8092 municipalities of Italy, from 2006 to 2015. A satellite-based spatiotemporal model was developed to estimate daily $\mathrm{PM}_{10}$ (inhalable particles) and $\mathrm{PM}_{2.5}$ (fine particles) concentrations at $1-\mathrm{km}$ resolution. Multivariate Poisson regression models were fit to estimate the association between daily PM and mortality at province level, and then, results were pooled with a random-effects meta-analysis. Associations were estimated by combination of age and sex and degree of urbanization of the municipalities. Flexible functions were estimated to explore the shape of the associations at low PM concentrations. Results: We analyzed 5,884,900 deaths (40\% among subjects older than 85 years, $60 \%$ occurring outside the main urban areas). National daily mean (interquartile range) $\mathrm{PM}_{10}$ and $\mathrm{PM}_{2.5}$ concentrations were $23(14) \mu \mathrm{g} / \mathrm{m}^{3}$ and $15(11) \mu \mathrm{g} / \mathrm{m}^{3}$, respectively. Relative increases of mortality per $10 \mu \mathrm{g} / \mathrm{m}^{3}$ variation in lag $0-5$ (average of last six days since death) $\mathrm{PM}_{10}$ and $\mathrm{PM}_{2.5}$ were $1.47 \%$ (95\% Confidence Intervals (CI): $1.15 \%, 1.79 \%$ ) and $1.96 \%(1.33 \%, 2.59 \%)$, respectively. Associations were highest among elderly and women for $\mathrm{PM}_{10}$ only, similar between rural and urbanized areas, and were present even at low concentrations, e.g., below WHO guidelines. Conclusions: Air pollution was robustly associated with peaks in daily all-cause mortality in Italy, both in large cities and in less urbanized areas of Italy. Current WHO Air Quality Guidelines (2021) for $\mathrm{PM}_{10}$ and $\mathrm{PM}_{2.5}$ are not sufficient to protect public health.
\end{abstract}

Keywords: air pollution; mortality; nationwide; urbanization; geographical differences; low concentrations

\section{Introduction}

Ambient air pollution is one of the most important risk factors for the human health worldwide. The World Health Organization (WHO) estimated that air pollution causes 4.2 million of deaths each year [1], which accounts for $6 \%$ of total deaths worldwide [2]. Moreover, in the last Global Burden of Diseases (GBD) [3] report, it has been observed that death rates related to outdoor air pollution are highest among the elderly [4]. In Italy, more than $20 \%$ of the population is aged over 65 years [5], making the health burden associated to air pollution a priority on the public health agenda. This implies the need for adequate measures to reduce air pollution levels.

During the last decades, many epidemiological studies have been conducted to assess the association between short-term exposure to outdoor air pollution and daily mortality [6-8]. Most studies have focused on particulate matter (PM) with a diameter of less 
than $10\left(\mathrm{PM}_{10}\right)$ or $2.5\left(\mathrm{PM}_{2.5}\right)$ micron [9-12], and a recent multi-country multi-city studied reported percent increases in risk per 10 -unit increase of pollutant about $0.44 \%$ and $0.55 \%$, respectively [8]. A recent systematic review that included 196 quantitative studies showed the harmful effects of $\mathrm{PM}_{10}$ and $\mathrm{PM}_{2.5}$ on all-cause and cause-specific (cardiovascular and respiratory) mortality [13]. In Italy, the Epiair and Epiair2 studies included 10 and 25 Italian cities, respectively, and reported significant effects of both $\mathrm{PM}_{10}$ and $\mathrm{PM}_{2.5}$ on cause-specific mortality and disease-specific hospital admissions [9,14]. Similarly, the European MEDPARTICLES project, which comprised 11 cities from three Mediterranean countries (Greece, Italy and Spain) as well as eight Italian cities, reported similar findings [11,15]. In particular, the authors reported a pooled estimate of $\sim 0.5 \%$ risk increases per 10-unit increase in $\mathrm{PM}_{2.5}$ and $\mathrm{PM}_{10}$, which was approximately constant in the eight Italian cities.

To date, most of the studies were conducted in urban settings due to the location of air pollution monitoring stations in cities and health data availability. In the last few years, satellite observations have been increasingly used as alternative air pollution exposure data, as they provide relevant information to supplement ground-level measurements and offer a complete spatial coverage. Machine-learning methodologies have been recently applied in Italy considering satellite data, dispersion models, and land-use terms to estimate daily concentration of $\mathrm{PM}_{10}(2006-2015)$ and $\mathrm{PM}_{2.5}$ (2013-2015) at $1 \times 1-\mathrm{km}$ spatial resolution [16,17].

Due to the lack of data, little is known on particulate matter-related health effects in rural and suburban areas. Only few studies have focused on the different effects in these settings. Recently, Italian rural areas were considered in a study on the short-term exposure to PM on cardiovascular hospital admissions [18]. The authors assessed the associations both in urban and rural areas to test potential different effects. They found no differences in effect estimates between urban and non-urban areas. Moreover, the study allowed a comparison in the health effects of air pollution in the different geographical areas in Italy, which are characterized by a north-to-south decreasing trend in exposure [16,17] and socio-economic differentials [19], as reported in the annual Italian report of the National Institute of Statistics (ISTAT). Finally, most of the evidence about the PM-related health effects in Italy involved only cities of northern Italy.

Estimates from different settings are important not only to have a more thorough and complete picture of the short-term effects of air pollution at population level across the entire geographical domain but also to improve the knowledge basis on low-level exposure effects. Recently, a U.S. study conducted on the Medicare population, a cohort of subjects aged 65 years and over enrolled in the U.S. health insurance system, showed a significant effect of $\mathrm{PM}_{2.5}$ on mortality also for exposure levels below the U.S. standard $\left(35 \mu \mathrm{g} / \mathrm{m}^{3}\right)[20,21]$ In Europe, similar results were provided by an Italian study conducted at national level, which showed a positive association between $\mathrm{PM}_{2.5}$ and cardiovascular hospitalizations for low concentrations [18]. Currently, the European Air Quality legislation has fixed the limit of daily concentration of $\mathrm{PM}_{2.5}$ to $15 \mu \mathrm{g} / \mathrm{m}^{3}$ and for $\mathrm{PM}_{10}$ to $45 \mu \mathrm{g} / \mathrm{m}^{3}$, assuming there are no health effects below these levels.

The main objective of this study is to provide new evidence on the differential effects of short-term exposure to $\mathrm{PM}_{10}$ and $\mathrm{PM}_{2.5}$ on all-cause mortality across the entire Italian domain and by urban, sub-urban, and rural administrative settings. A secondary aim is to estimate the shape of the exposure-response function with a focus on the low levels of PM. Finally, we aimed to evaluate individual characteristics (sex and age) as potential effect modifiers of the PM-mortality association.

\section{Material and Methods}

\subsection{Study Area}

Italy is located in Southern Europe; it extends over $301,340 \mathrm{~km}^{2}$ and is divided into 8092 municipalities grouped into 110 administrative provinces, with a total population of $60,483,973$ inhabitants in 2017 and a median number of inhabitants per municipality equal to 2438 (interquartile range, $\mathrm{IQR}=5084$ ). 


\subsection{Environmental Data}

For each day, PM values were extracted by satellite information and refined by randomforest models. Details are available here [16,17]. Briefly, spatial and spatiotemporal predictors (e.g., aerosol optical depth (AOD), land use, and meteorological data) were obtained daily (2006-2015 for $\mathrm{PM}_{10}$ and 2013-2015 for $\left.\mathrm{PM}_{2.5}\right)$ and for each grid cell $(1 \times 1 \mathrm{~km})$ of Italy. Models based on a four-stages approach using the spatial and spatiotemporal predictors were applied to predict daily mean values of $\mathrm{PM}_{10}$ and $\mathrm{PM}_{2.5}$ concentrations for each spatial unit $\left(1 \mathrm{~km}^{2}\right)$ of Italy. We limited the calculation for $\mathrm{PM}_{2.5}$ on the 2013-2015 period due to lack of monitoring data. Cross-validated $\mathrm{R}^{2}$ were 0.75 and 0.81 for $\mathrm{PM}_{10}$ and $\mathrm{PM}_{2.5}$, respectively.

We obtained daily values of air and dew point temperatures from the ERA-5 reanalysis model [22], released by the European Centre for Medium-Range Weather Forecasts (ECMWF). We collected data on air and dew point temperature estimated at 2-m height at $0.00 \mathrm{a} . \mathrm{m}$. and 12.00 p.m. with a spatial resolution of $0.125^{\circ} \times 0.125^{\circ}$ (approximately $10 \times 10 \mathrm{~km}$ ). We calculated daily mean values of air and dew point temperature by averaging the two daily retrievals. We finally calculated the daily apparent temperature using the formula (1).

$$
\mathrm{AT}=-2.653+(0.994 \times \mathrm{Ta})+\left(0.0153 \times \mathrm{Td}^{2}\right)
$$

where $\mathrm{Ta}$ is air temperature, and $\mathrm{Td}$ is dew point temperature. Apparent temperature (AT) is an index of human discomfort during hot and humid days, defined as a person's perceived air temperature $[23,24]$.

Lastly, we computed daily PM and apparent temperature for each municipality by averaging the grid-based estimates from the cells intersecting each spatial unit, with weights proportional to the intersection areas.

\subsection{Health Data}

We collected information on deaths from the National Institute of Statistics (ISTAT). We computed daily counts of all-cause deaths for each municipality and also by sex and age group: 0-64, 65-74, 75-84, and 85+ years.

\subsection{Statistical Analysis}

We estimated the association between all-cause mortality and $\mathrm{PM}_{10}$ and $\mathrm{PM}_{2.5}$ by applying a pooled analysis by province. Italy is divided into 110 administrative provinces, which have on average 74 cities (range 6-315). Province-specific analyses were applied to better adjust for some confounders, such as time trends and temperature, but also for computational issues. In this way, we built 110 province-specific datasets based on dailyand city-specific observations. As a second step, we ran random-effects meta-analysis to pool the 110 province-specific estimates obtained in the first step.

We used the time-series study design with over-dispersed Poisson regression models to estimate the associations between daily exposure to PM at different time-windows (lag) and daily numbers of deaths. The associations were adjusted for time-trends, temperature, city indicator, national holidays, summer population decreases, and regional-specific influenza epidemics.

More details are provided in the Supplemental Data.

We defined three-time windows of PM exposure to evaluate the immediate (lag 0 and lag $0-1$ ), delayed (lag 2-5), and prolonged effects (lag 0-5).

We tested for effect modification by combination of sex and age class (divided in eight classes: 0-64 males, 0-64 females, 65-74 males, 65-74 females, 75-84 males, 75-84 females, $85+$ males, and $85+$ females) by creating daily stratum-specific counts. We decided to analyze those potential effect modifiers together to better consider the different age composition between sexes. In addition, we evaluated a potential effect modification by degree of municipality urbanization using a stratified approach. We ran the analysis in a province- and urbanization level-specific datasets. We used the degree of urbanization (DEGURBA) classification with 3 levels of urbanization (urban, suburban, and rural), 
obtained by EUROSTAT [25]. In addition, as a sensitivity analysis, we also considered as an index of urbanization provided by ISTAT, which classifies each municipality by using socio-demographic characteristics, such as the average distance to local and health services, etc. (www.istat.it, (accessed on 1 April 2021)). More information is provided in the supplemental material.

We estimated exposure-response functions for each outcome by applying distributedlag non-linear models (DLNM) in each municipality and pooling the resulting curves using a multivariate meta-regression [26] in order to capture the heterogeneity of estimates across space. Specifically, we modelled the function by using natural splines with 3 degrees of freedom. Exposure-response functions were extrapolated also by level of urbanization.

Finally, risk maps for both $\mathrm{PM}_{10}$ (2006-2015) and $\mathrm{PM}_{2.5}$ (2013-2015) are provided by region to explore the geographical differences. Regional estimates were obtained by meta-analysis of province-specific results for each Region.

Results are provided as the percent difference of mortality (with $95 \%$ confidence intervals $(95 \% \mathrm{CI})$ ) relative to $10 \mu \mathrm{g} / \mathrm{m}^{3}$ fixed increases in PM. We conducted all analyses with R (version 3.1.3; Institute for Statistics and Mathematics, WU Wien, Vienna, Austria).

\section{Results}

The average value of $\mathrm{PM}_{10}$ was $23.3 \mu \mathrm{g} / \mathrm{m}^{3}$ (standard deviation = 14.2) during the whole study period and 21.1 (13.6), and $15.1(10.9) \mu \mathrm{g} / \mathrm{m}^{3}$ during the last three years of the study (2013-2015) for $\mathrm{PM}_{10}$ and $\mathrm{PM}_{2.5}$, respectively. The interquartile ranges (IQR), calculated as the difference between the 75th and 25th percentile, were 12.4 and $8.3 \mu \mathrm{g} / \mathrm{m}^{3}$ for $\mathrm{PM}_{10}$, and $\mathrm{PM}_{2.5}$ in the entire (2006-2015) and restricted (2013-2015) periods, respectively. Finally, mean values of air and apparent temperature were $11.8^{\circ} \mathrm{C}$ and $10.9^{\circ} \mathrm{C}$, respectively (Table 1).

Table 1. Description of the environmental data for the study period 2006-2015, overall and by level of urbanization score (in bold) in Italy. Data are reported for the long period (2006-2015) regarding $\mathrm{PM}_{10}$ and temperature for the restricted period (2013-2015) regarding $\mathrm{PM}_{2.5}$.

\begin{tabular}{|c|c|c|c|c|c|c|c|c|c|}
\hline \multicolumn{3}{|l|}{ Variable } & \multicolumn{7}{|c|}{ Percentiles } \\
\hline Overall & & Mean & SD & Min & 25th & 50th & 75th & Max & IQR \\
\hline $\mathrm{PM}_{10}$ & $\mu \mathrm{g} / \mathrm{m}^{3}$ & 23.3 & 14.2 & 1.8 & 14.6 & 19.7 & 27.0 & 290.2 & 12.4 \\
\hline $\mathrm{PM}_{2.5}$ & $\mu \mathrm{g} / \mathrm{m}^{3}$ & 15.1 & 10.9 & 1.3 & 8.7 & 11.6 & 16.9 & 163.4 & 8.3 \\
\hline Temperature & ${ }^{\circ} \mathrm{C}$ & 11.8 & 8.0 & -23.2 & 6.0 & 12.0 & 17.8 & 35.8 & 11.8 \\
\hline \multicolumn{10}{|l|}{ Rural areas } \\
\hline $\mathrm{PM}_{10}$ & $\mu \mathrm{g} / \mathrm{m}^{3}$ & $20.8 *$ & 12 & 1.8 & 13.6 & 18.0 & 24.0 & 275.7 & 9.4 \\
\hline $\mathrm{PM}_{2.5}$ & $\mu \mathrm{g} / \mathrm{m}^{3}$ & 13.5 * & 9.4 & 1.6 & 8.2 & 10.7 & 15.1 & 157.0 & 6.9 \\
\hline \multicolumn{10}{|l|}{ Suburban areas } \\
\hline $\mathrm{PM}_{10}$ & $\mu \mathrm{g} / \mathrm{m}^{3}$ & $28.0 *$ & 16 & 2.1 & 17.8 & 23.6 & 32.5 & 290.2 & 14.7 \\
\hline $\mathrm{PM}_{2.5}$ & $\mu \mathrm{g} / \mathrm{m}^{3}$ & 18.0 * & 12.6 & 1.3 & 10.1 & 13.8 & 21.0 & 163.4 & 10.9 \\
\hline \multicolumn{10}{|l|}{ Urban areas } \\
\hline $\mathrm{PM}_{10}$ & $\mu \mathrm{g} / \mathrm{m}^{3}$ & $34.1 *$ & 21 & 2.7 & 21.4 & 28.0 & 39.0 & 283.6 & 17.6 \\
\hline $\mathrm{PM}_{2.5}$ & $\mu \mathrm{g} / \mathrm{m}^{3}$ & $21.3 *$ & 15.6 & 1.3 & 11.3 & 15.6 & 25.1 & 158.3 & 13.8 \\
\hline
\end{tabular}

A total of 5,884,900 deaths for all causes were registered during the 2006-2015 period, while 1,839,300 were observed in the last three years (2013-2015) in Italy (Table 2). Overall, $48 \%$ of all deaths were among males, and $40 \%$ were among subjects aged 85 years and over. Urban and suburban areas accounted for $80 \%$ of total deaths, while only $20 \%$ were observed in rural areas. 
Table 2. Description of the health data by individual characteristics (in bold) for the study period 2006-2015 overall and by level of urbanization score in Italy.

\begin{tabular}{cccccccc}
\hline & Urban & \multicolumn{3}{c}{ Suburban } & \multicolumn{2}{c}{ Rural } & Overall \\
\hline Total & $\mathrm{N}$ & $\%$ & $\mathrm{~N}$ & $\%$ & $\mathrm{~N}$ & $\%$ & $\mathrm{~N}$ \\
Age 0-64 & $2,323,100$ & 39.5 & $2,370,200$ & 40.3 & $1,191,700$ & 20.3 & $5,884,900$ \\
Age 65-74 & 358,660 & 47.2 & 274,660 & 36.1 & 127,230 & 16.7 & 760,550 \\
Age 75-84 & 384,380 & 43.4 & 348,830 & 39.4 & 151,540 & 17.1 & 884,750 \\
Age 85+ & 746,640 & 39.3 & 779,680 & 41.0 & 374,070 & 19.7 & $1,900,400$ \\
Males & 833,280 & 35.6 & 966,930 & 41.3 & 538,830 & 23.0 & $2,339,000$ \\
Females & $1,143,800$ & 40.0 & $1,144,400$ & 40.0 & 570,930 & 20.0 & $2,859,100$ \\
& $1,179,300$ & 39.0 & $1,225,700$ & 40.5 & 620,780 & 20.5 & $3,025,800$ \\
\hline
\end{tabular}

Each $10-\mu \mathrm{g} / \mathrm{m}^{3}$ increase in $\mathrm{PM}_{10}$ was associated with statistically significant increments in mortality for each lag considered, with a percent change in risk up to 1.47 (95\% CI: $1.16,1.79)$ at lag $0-5$ during the period 2006-2015. In the restricted period, similar positive associations for both $\mathrm{PM}_{10}$ and $\mathrm{PM}_{2.5}$ were observed with percent changes of $1.20 \%$ (95\%CI: $0.84,1.57)$ and $1.96 \%(95 \% \mathrm{CI}: 1.33,2.59)$, respectively, at lag 0-5 (Figure 1).

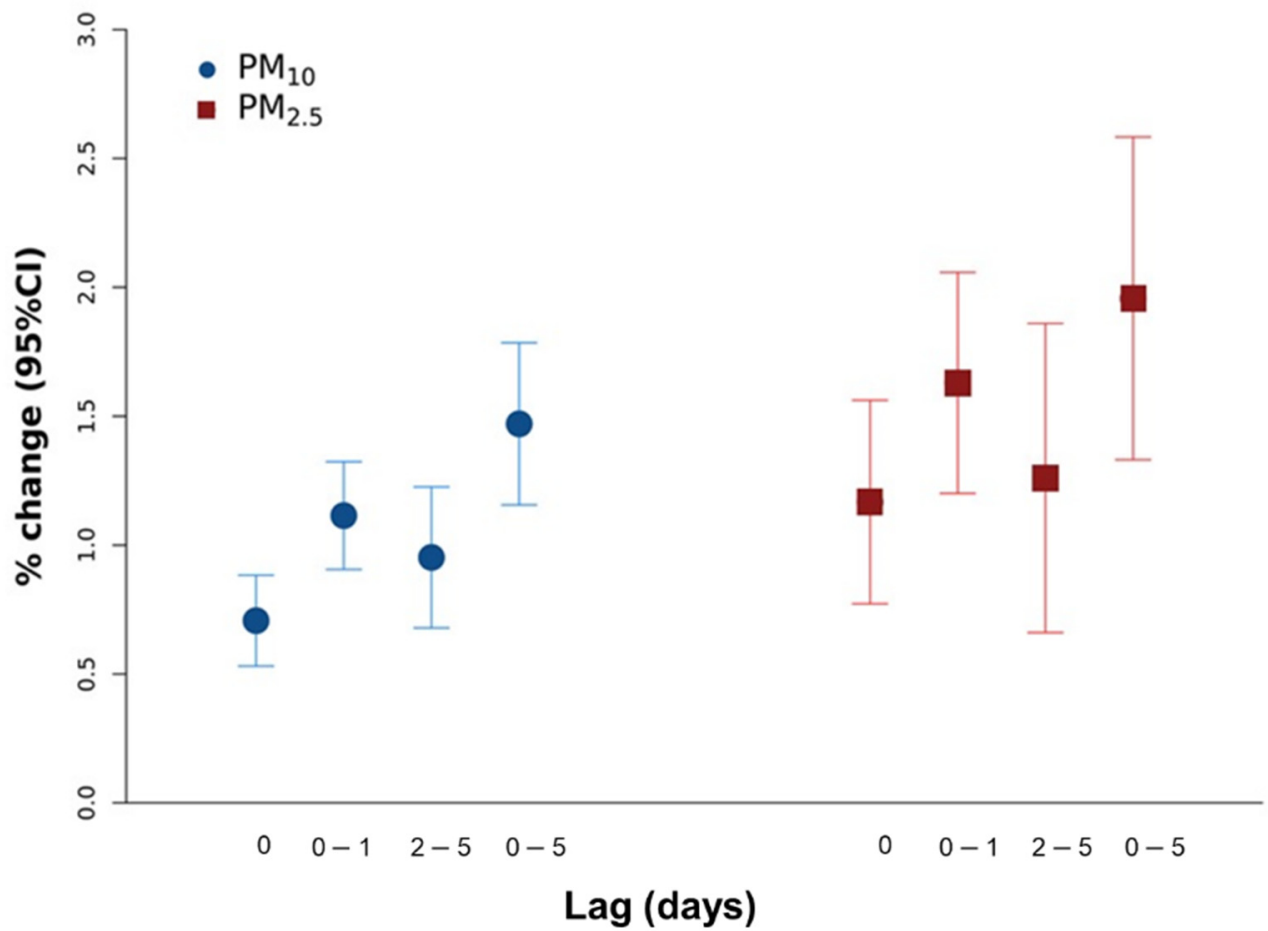

Figure 1. Associations between short-term exposure at different time windows (lag 0, 0-1, 2-5, 0-5) to $\mathrm{PM}_{10}$ and $\mathrm{PM}_{2.5}$ and all-cause mortality during 2006-2015 period for $\mathrm{PM}_{10}$ (blue dots) and 2013-2015 for $\mathrm{PM}_{2.5}$ (red dots). Results are from random effects meta-analysis of Italian province-specific estimates (110 provinces) and are expressed as percent change of risk and relative $95 \%$ confidence intervals per $10 \mu \mathrm{g} / \mathrm{m}^{3}$ increases.

Table 3 shows effect modification by age and sex for $\mathrm{PM}_{10}$ (2006-2015) and $\mathrm{PM}_{2.5}$ (2013-2015). We observed an increasing trend in the risk of mortality by age in both sexes. The highest effects are among females aged 85 years and over for $\mathrm{PM}_{2.5}$ (3.07\%: 95\%CI: $2.07,4.09)$ and among males aged $75-84$ years $(3.16 \%$ : 95\%CI: $1.46,4.89)$. 
Table 3. Effect modification for age class and sex between $\mathrm{PM}_{10}$ and $\mathrm{PM}_{2.5}$ at lag $0-5$ and all-cause mortality during 2006-2015 period for $\mathrm{PM}_{10}$ and 2013-2015 for and $\mathrm{PM}_{2.5}$. Results are expressed as percent change of risk and relative 95\% confidence intervals per $10 \mu \mathrm{g} / \mathrm{m}^{3}$ increases.

\begin{tabular}{|c|c|c|c|c|c|c|c|}
\hline \multirow{2}{*}{ Age Class } & \multirow{2}{*}{ Sex } & \multicolumn{3}{|c|}{$\mathbf{P M}_{10}$} & \multicolumn{3}{|c|}{$\mathrm{PM}_{2.5}$} \\
\hline & & \multirow{2}{*}{$\begin{array}{c}\text { \% Change } \\
-0.33\end{array}$} & \multicolumn{2}{|c|}{$95 \%$ CI } & \multirow{2}{*}{$\begin{array}{c}\text { \% Change } \\
-0.21\end{array}$} & \multicolumn{2}{|c|}{$95 \%$ CI } \\
\hline \multirow[t]{2}{*}{$0-64$} & Females & & -1.86 & 1.22 & & -5.23 & 5.06 \\
\hline & Males & -0.18 & -1.14 & 0.78 & -1.17 & -3.46 & 1.18 \\
\hline \multirow[t]{2}{*}{$65-74$} & Females & 0.34 & -0.76 & 1.44 & 0.45 & -2.20 & 3.18 \\
\hline & Males & 0.27 & -0.63 & 1.18 & 0.09 & -1.76 & 1.98 \\
\hline \multirow[t]{2}{*}{$75-84$} & Females & 1.68 & 1.01 & 2.35 & 1.42 & -0.59 & 3.48 \\
\hline & Males & 1.53 & 0.90 & 2.17 & 3.16 & 1.46 & 4.89 \\
\hline \multirow[t]{2}{*}{$85+$} & Females & 2.73 & 2.21 & 3.26 & 3.07 & 2.07 & 4.09 \\
\hline & Males & 1.74 & 0.84 & 2.64 & 3.10 & 1.21 & 5.02 \\
\hline
\end{tabular}

When we evaluated urbanization as an effect modifier of the PM-mortality association, estimates were very similar, and we could not detect meaningful differences between rural, sub-urban, and urban areas (Figure 2), an important result demonstrating adverse effects of air pollution even outside major cities.

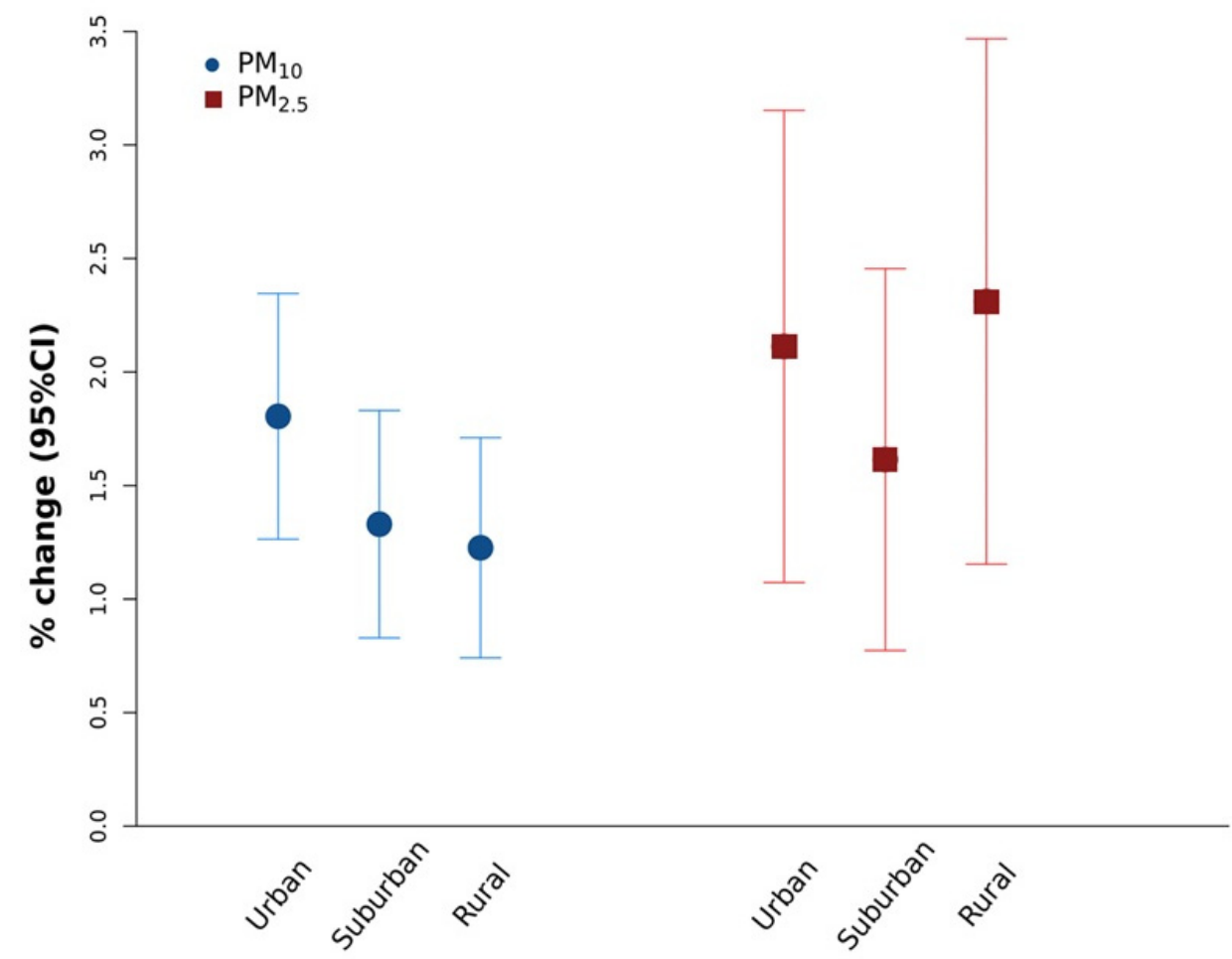

Figure 2. Effect modification for urbanization level (in 3 classes: rural, suburban, and urban cities) between $\mathrm{PM}_{10}$ and $\mathrm{PM}_{2.5}$ at lag 0-5 and all-cause mortality during 2006-2015 period for $\mathrm{PM}_{10}$ and 2013-2015 for and $\mathrm{PM}_{2.5}$. Results are expressed as percent change of risk and relative 95\% confidence intervals per $10 \mu \mathrm{g} / \mathrm{m}^{3}$ increases.

Figure 3 displays the pooled exposure-response functions for all-cause mortality at lag 0-5 for both $\mathrm{PM}_{10}$ and $\mathrm{PM}_{2.5}$. Both $\mathrm{PM}_{10}$ and $\mathrm{PM}_{2.5}$ exposure-responses curves were almost linear. The $\mathrm{PM}_{2.5}$ curve shows a steady increase in effect estimates for increases in $\mathrm{PM}$, and for higher concentrations $\left(35-40 \mu \mathrm{g} / \mathrm{m}^{3}\right)$, it reaches a plateau when effects seem to remain constant thereafter. The $\mathrm{PM}_{10}$ curve is consistent with a linear trend. For both PM exposures, we found increased mortality risk below the current WHO guideline values for daily means of $15\left(\mathrm{PM}_{2.5}\right)$ and $45\left(\mathrm{PM}_{10}\right) \mu \mathrm{g} / \mathrm{m}^{3}$. 

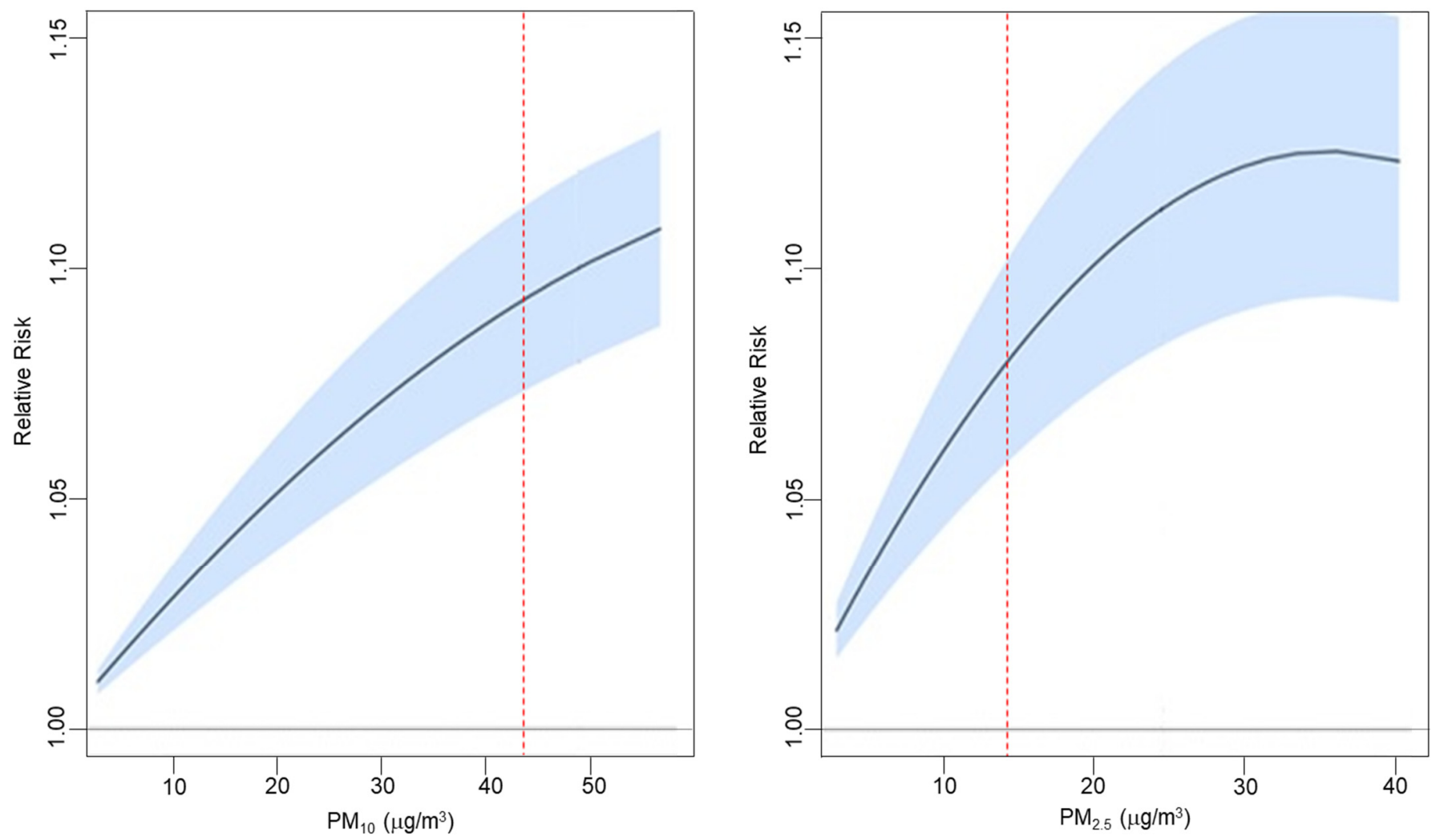

Figure 3. Exposure-response functions for $\mathrm{PM}_{10}$ (2006-2015) and $\mathrm{PM}_{2.5}$ (2013-2015) and all-cause mortality at lag 0-5 in Italy. Red line represents the meta-curve obtained by the 110 province-specific estimates. Red lines represent WHO guideline values for daily mean concentrations.

In Figure 4 region-specific effect estimates are reported for $\mathrm{PM}_{10}$ and $\mathrm{PM}_{2.5}$ at lag 0-5, respectively. Maps shows no clear geographic trend with positive associations in most regions; however, some regions in the south of Italy seem to have slightly higher effect estimates (Apulia, Sicily, Calabria). Some small mountainous regions (Valle d'Aosta, Trentino Alto Adige) or islands, such as Sardinia, showed no effect possibly due to sparse data. 


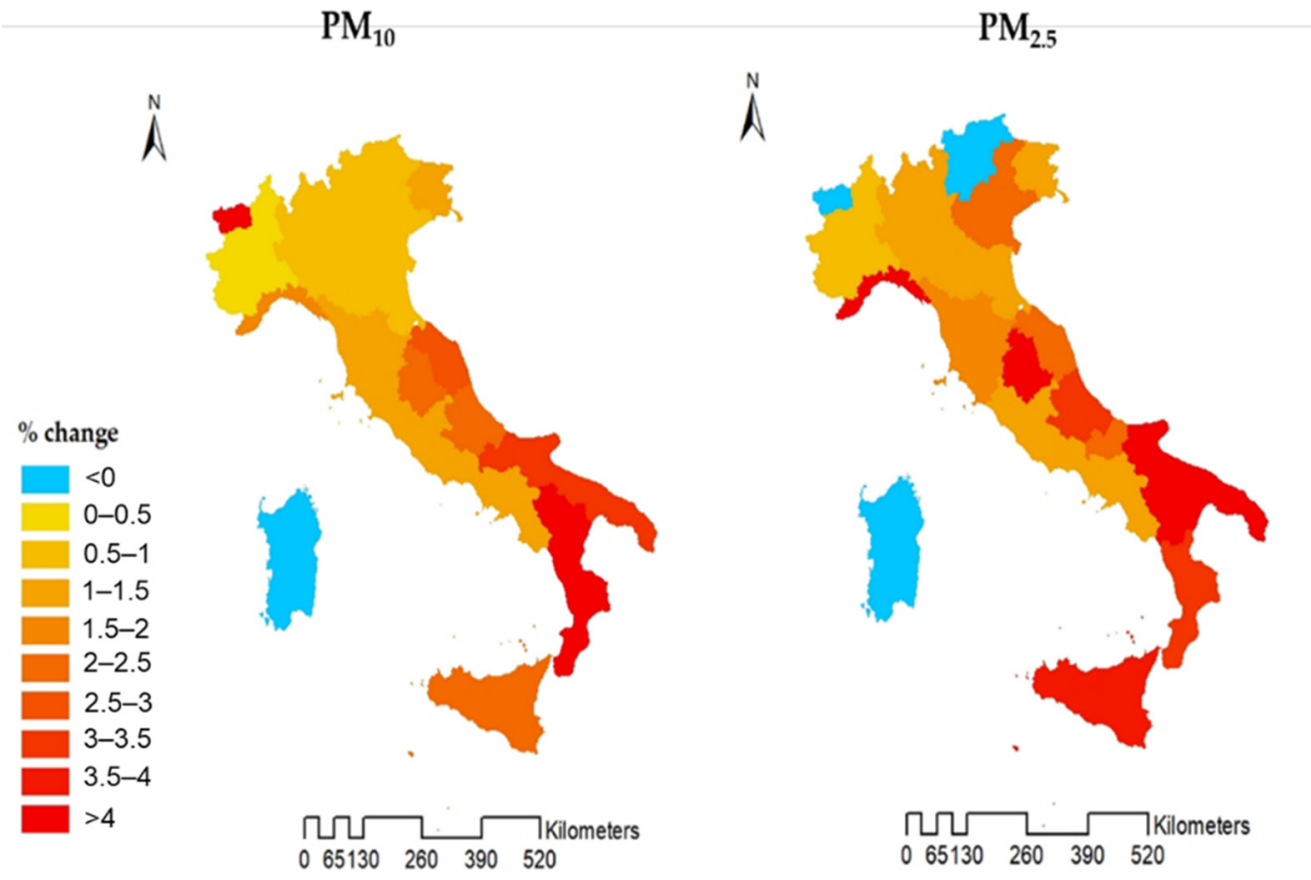

Figure 4. Association between $\mathrm{PM}_{10}$ and $\mathrm{PM}_{2.5}$ exposures at lag $0-5$ and all-cause mortality in 20 Italian regions during 2006-2015 ( $\left.\mathrm{PM}_{10}\right)$ and 2013-2015 $\left(\mathrm{PM}_{2.5}\right)$ periods. Not statistically significant results are dulled. Results are expressed as \% change of risk.

\section{Discussion}

In this paper, we investigated the short-term effects of $\mathrm{PM}_{10}$ and $\mathrm{PM}_{2.5}$ on all-cause mortality in the period 2006-2015 across the entire Italian domain using high-resolution exposure data and municipality-level mortality data. We found a positive association for both $\mathrm{PM}_{10}$ and $\mathrm{PM}_{2.5}$ and mortality with higher effects at the cumulative exposure level (lag 0-5 days). Significant effects were observed for both $\mathrm{PM}_{10}$ and $\mathrm{PM}_{2.5}$, starting form very low concentrations below the current $\mathrm{EU}$ air quality standards and $\mathrm{WHO}$ guidelines. We found a greater risk among the elderly and comparable effects in rural, suburban, and urban settings.

The association between short-term exposure to $\mathrm{PM}_{10}$ and $\mathrm{PM}_{2.5}$ and mortality has been well documented in the epidemiological literature. Recently, a systematic review collected information from 196 quantitative studies [13]. Specifically, the authors reported 66 studies on the acute exposure to $\mathrm{PM}_{10}$ and all-cause mortality and 29 studies focusing on $\mathrm{PM}_{2.5}$-related effects. In both cases, they found a positive association between PM and mortality, with percent changes in risk of 0.4 ( $80 \%$ prediction intervals: $0.3,0.5 \%)$ and 0.7 (80\%PI: $0.4,0.9 \%)$ for a $10-\mu \mathrm{g} / \mathrm{m}^{3}$ increase in PM. In our studies, risk estimates were much higher for both $\mathrm{PM}_{10}$ and $\mathrm{PM}_{2.5}$. These differences might be due to a diverse setting (nationwide vs. multi-cities) considered in the studies. For example, in the multicities studies, only urban areas were considered, while in nationwide studies like ours, the heterogeneity is greater due to the diversity of settings considered both in terms of population size and characteristics, level of urbanization, and geographical context, which is characterized by different areas with higher heterogeneity. Previous estimates for Italy were provided by the Epiair multicity study [9]. Findings from the mortality study on 25 Italian cities in the period $2006-2010$ showed a mortality risks of $0.51 \%(0.16 \%, 0.86 \%)$ and $0.78 \%(0.12 \%, 1.46 \%)$, respectively, for a $10-\mu \mathrm{g} / \mathrm{m}^{3}$ increase in $\mathrm{PM}_{10}$ and $\mathrm{PM}_{2.5}$. Worldwide similar estimates were observed in the recent multi-country study conducted in 652 cities by the Multi-City Multi-Country (MCC) Collaborative Research Network [8]. Higher effects of $\mathrm{PM}_{2.5}$ compared to $\mathrm{PM}_{10}$ have been commonly found in the epidemiological literature $[9,27]$. These results may be supported by the abundant evidence that this 
particulate fraction contains far more smaller particles that can absorb toxic components from the air and penetrate deep into the lungs [8,28].

Biological mechanisms underlying the association between inhalation of PM and health outcomes, such as mortality, have been widely investigated in the last years [12,29-32]. A recent clinical trial demonstrated that higher PM exposures can activate the human central nervous system, which induces the production of hormones as glucocorticoids, corticotropin-releasing hormone, and adrenocorticotropic hormone [32]. These processes are involved in physiological pathways for the increase in blood pressure and insulinresistance, which are related to major health outcomes.

The joint interaction between age and sex showed an increasing trend in the mortality risk by age for both males and females. Moreover, we found different trends among the very old ( $>85$ years) between sexes with higher $\mathrm{PM}_{10}$-related effects in females compared to males and the opposite for $\mathrm{PM}_{2.5}$. Some studies described higher effects in women among elderly subjects [33-35]. Hong et al. found that elderly women were most susceptible to the adverse effects of $\mathrm{PM}_{10}$ on the risk of acute mortality from stroke [35], while Bateson and Schwartz observed a higher risk of mortality for acute $\mathrm{PM}_{10}$ exposure among elderly women and men aged 65-75 years old [33], similar to our findings for Italy. When considering differential effects by age, it has been reported that some inflammatory markers, such as the C-reactive protein, increased with age [36], causing a worsening health status and higher frailty [37]. Differences between males and females in PM-related health effects might be related to physiological (smaller airways, greater airway reactivity, and greater deposition of $\mathrm{PM}_{2.5}$ [38]), hormonal, biological, structural, and morphological differences in the two sexes [39].

Given the high-resolution dataset and national coverage, we were able to estimate PMrelated mortality risks in urban and sub-urban and rural settings, for which, to date, there is limited evidence. It is worth mentioning that, in less urbanized municipalities, access to health care and services is limited, the population is generally older, with potentially less economical resources and characterized by worse lifestyle habits, such as smoking and diet (www.istat.it, (accessed on 1 April 2021)). All these factors may render the population less resourceful, with a worse general health status, and air pollution might act as an easy trigger for mortality.

The exposure response functions showed a linear or quasi-linear association between PM exposure and mortality as previously documented [40,41], with an increase in the risk even for low PM concentrations well below the EU limits and WHO guidelines. These results confirm some recent epidemiological findings; Hanigan et al. investigated the role of long-term exposure to air pollution on all-cause mortality in a Australian cohort [42]. The authors found that each 1-unit increase in $\mathrm{PM}_{2.5}$ exposure led to a 5\% $(-2,12 \%)$ increase in the risk of dying, even for low average exposure levels of $4.5 \mu \mathrm{g} / \mathrm{m}^{3} \mathrm{PM}_{2.5}$. Despite that the study focused on the long-term effects of PM, which display different mechanisms than short-term associations, the evidence showed the harmful role of air pollution even at low concentrations. Similarly, a study conducted in the U.S. on a cohort of elderly Medicare patients found a $1.61 \%(1.48,1.74 \%)$ increase in the risk of mortality for a 10-unit change in $\mathrm{PM}_{2.5}$ when considering days with PM below the daily National Ambient Air Quality Standards (NAAQS) limit of $35 \mu \mathrm{g} / \mathrm{m}^{3}$ [20]. Current daily $\mathrm{PM}_{10}$ and $\mathrm{PM}_{2.5}$ air quality standards should be amended to account for more recent findings on the health effects at lower levels.

Finally, we explored the spatial heterogeneity of PM-related health effects across the 20 Italian Regions. We did not observe considerable differences in the risk across regions in Italy, while some consistency was observed in effect estimates in the southern regions of Italy, with slightly higher values. Moreover, it is worth mentioning there are mortality inequalities in Italy, with a typical north-south gradient related to socio-economic and educational level differences [43]. However, this is only a speculative hypothesis because we do not have information on educational level or socio-economic factors that might act as an effect modifier to address this. It will be a matter for further studies in the field in Italy. 
This study has some limitations that should be addressed. Firstly, we only had total mortality and were not able to disaggregate mortality by cause or distinguish accidental and natural causes, and this might introduce a slight misclassification bias. Secondly, although our exposure allowed for a national spatial coverage with high spatial resolution compared to point-monitoring data, we still considered daily average exposure at municipality level derived by $1-\mathrm{km}^{2}$ daily estimations, which can introduce a Berkson's type bias. Finally, the lack of individual information, such as clinical history or individual characteristics and behaviors, did not allow to evaluate effect modification for such covariates.

\section{Conclusions}

The study provides evidence of harmful effects of both $\mathrm{PM}_{10}$ and $\mathrm{PM}_{2.5}$ on all-cause mortality in urban, rural, and sub-urban settings in Italy from very low PM concentrations. Greater effects were observed among the elderly. Results seem to confirm that not only urban settings are exposed to harmful pollutants and that local policies and awareness campaigns regarding the PM-related health effects should be extended to sub-urban and rural settings.

Supplementary Materials: The following are available online at https://www.mdpi.com/article/10 .3390/ijerph182412895/s1.

Author Contributions: M.R. contributed to the study design, conducted the statistical analyses, and wrote the paper. F.d.D. contributed to the study design and reviewed the paper. P.M. contributed to the study design and to the discussion. M.D. contributed to the study design and the discussion. S.M. contributed to the study design, to the discussion, and the revision of the paper. M.P. contributed to the study design, to the discussion, and the revision of the paper. M.S. (Matteo Scortichini) contributed to the statistical analyses and to the discussion. L.F. contributed to the study design and to the discussion. M.S. (Massimo Stafoggia) contributed to the study design, to the statistical plan, and writing the paper. All authors have read and agreed to the published version of the manuscript.

Funding: CCM Azioni centrali 2020: Rafforzamento sistema di Sorveglianza della Mortalità Giornaliera (SiSMG): J85H20000230001; EXHAUSTION—Exposure to heat and air pollution in EUropecardiopulmonary impacts and benefits of mitigation and adaptation: H2020-LC-CLA-2018-2.

Institutional Review Board Statement: Not applicable.

Informed Consent Statement: Not applicable.

Data Availability Statement: The data that support the findings of this study are available on request from the corresponding author (M.R.). The data are not publicly available due to privacy restriction, as they contain information that could compromise research participant privacy/consent.

Conflicts of Interest: The authors declare no conflict of interest.

\section{References}

1. World Health Organization. Ambient Air Pollution: A Global Assessment of Exposure and Burden of Disease; World Health Organization: Geneva, Switzerland, 2016.

2. Ritchie, H. Outdoor Air Pollution. Available online: https:/ / ourworldindata.org/outdoor-air-pollution\#outdoor-air-pollutionis-one-of-the-leading-risk-factors-for-premature-death (accessed on 1 April 2021).

3. Stanaway, J.D.; Afshin, A.; Gakidou, E.; Lim, S.S.; Abate, D.; Abate, K.H.; Abbafati, C.; Abbasi, N.; Abbastabar, H.; Abd-Allah, F.; et al. Global, regional, and national comparative risk assessment of 84 behavioural, environmental and occupational, and metabolic risks or clusters of risks for 195 countries and territories, 1990-2017: A systematic analysis for the Global Burden of Disease Stu. Lancet 2018, 392, 1923-1994. [CrossRef]

4. World Health Organization. Ambient (Outdoor) Air Pollution. Available online: https://www.who.int/en/news-room/factsheets/detail/ambient--(outdoor)-air-quality-and-health (accessed on 1 April 2021).

5. Eurostat. People in the EU: Who Are We and How Do We Live; Publications Office of the European Union: Luxembourg, 2015.

6. Atkinson, R.W.; Kang, S.; Anderson, H.R.; Mills, I.C.; Walton, H. A Epidemiological time series studies of $\mathrm{PM}_{2.5}$ and daily mortality and hospital admissions: A systematic review and meta-analysis. Thorax 2014, 69, 660-665. [CrossRef]

7. Di, Q.; Wang, Y.; Zanobetti, A.; Wang, Y.; Koutrakis, P.; Choirat, C.; Dominici, F.; Schwartz, J.D. Air Pollution and Mortality in the Medicare Population. N. Engl. J. Med. 2017, 376, 2513-2522. [CrossRef] [PubMed] 
8. $\quad$ Liu, C.; Chen, R.; Sera, F.; Vicedo-Cabrera, A.M.; Guo, Y.; Tong, S.; Coelho, M.S.Z.S.; Saldiva, P.H.N.; Lavigne, E.; Matus, P.; et al. Ambient Particulate Air Pollution and Daily Mortality in 652 Cities. N. Engl. J. Med. 2019, 381, 705-715. [CrossRef]

9. Alessandrini, E.R.; Faustini, A.; Chiusolo, M.; Stafoggia, M.; Gandini, M.; Demaria, M.; Antonelli, A.; Arena, P.; Biggeri, A.; Canova, C.; et al. Air pollution and mortality in twenty-five Italian cities: Results of the EpiAir2 Project I Inquinamento atmosferico e mortalità in venticinque città Italiane: Risultati del progetto EpiAir2. Epidemiol. Prev. 2013, 37, 220-229. [PubMed]

10. Scarinzi, C.; Alessandrini, E.R.; Chiusolo, M.; Galassi, C.; Baldini, M.; Serinelli, M.; Faustini, A.; Stafoggia, M.; Gandini, M.; Antonelli, A.; et al. Inquinamento atmosferico e ricoveri ospedalieri urgenti in 25 città italiane: Risultati del progetto EpiAir2. Epidemiol. Prev. 2013, 37, 230-241. [PubMed]

11. Samoli, E.; Stafoggia, M.; Rodopoulou, S.; Ostro, B.; Declercq, C.; Alessandrini, E.; Díaz, J.; Karanasiou, A.; Kelessis, A.G.; Le Tertre, A.; et al. Associations between fine and coarse particles and mortality in Mediterranean cities: Results from the MED-PARTICLES project. Environ. Health Perspect. 2013, 121, 932-938. [CrossRef] [PubMed]

12. Mills, I.C.; Atkinson, R.W.; Kang, S.; Walton, H.; Anderson, H.R. Quantitative systematic review of the associations between short-term exposure to nitrogen dioxide and mortality and hospital admissions. BMJ Open 2015, 5, e006946. [CrossRef] [PubMed]

13. Orellano, P.; Reynoso, J.; Quaranta, N.; Bardach, A.; Ciapponi, A. Short-term exposure to particulate matter $\left(\mathrm{PM}_{10}\right.$ and $\left.\mathrm{PM}_{2.5}\right)$, nitrogen dioxide $\left(\mathrm{NO}_{2}\right)$, and ozone $\left(\mathrm{O}_{3}\right)$ and all-cause and cause-specific mortality: Systematic review and meta-analysis. Environ. Int. 2020, 142, 105876. [CrossRef] [PubMed]

14. Biggeri, A.; Baccini, M. [Short-term effects of air pollution in Italy: Risk heterogeneity from 1996 to 2005]. [Le stime italiane degli effetti a breve termine dell'inquinamento atmosferico: Metodi e risultati a confronto.]. Epidemiol. Prev. 2009, 33, 95-102. [PubMed]

15. Samoli, E.; Stafoggia, M.; Rodopoulou, S.; Ostro, B.; Alessandrini, E.; Basagaña, X.; Díaz, J.; Faustini, A.; Gandini, M.; Karanasiou, A.; et al. Which specific causes of death are associated with short term exposure to fine and coarse particles in Southern Europe? Results from the MED-PARTICLES project. Environ. Int. 2014, 67, 54-61. [CrossRef] [PubMed]

16. Stafoggia, M.; Schwartz, J.; Badaloni, C.; Bellander, T.; Alessandrini, E.; Cattani, G.; de' Donato, F.; Gaeta, A.; Leone, G.; Lyapustin, A.; et al. Estimation of daily PM10 concentrations in Italy (2006-2012) using finely resolved satellite data, land use variables and meteorology. Environ. Int. 2017, 99, 234-244. [CrossRef] [PubMed]

17. Stafoggia, M.; Bellander, T.; Bucci, S.; Davoli, M.; De Hoogh, K.; De Donato, F.; Gariazzo, C.; Lyapustin, A.; Michelozzi, P.; Renzi, M.; et al. Estimation of daily $\mathrm{PM}_{10}$ and $\mathrm{PM}_{2.5}$ concentrations in Italy, 2013-2015, using a spatiotemporal land-use random-forest model. Environ. Int. 2019, 124, 170-179. [CrossRef] [PubMed]

18. Stafoggia, M.; Renzi, M.; Forastiere, F.; Ljungman, P.; Davoli, M.; de' Donato, F.; Gariazzo, C.; Michelozzi, P.; Scortichini, M.; Solimini, A.; et al. Short-term effects of particulate matter on cardiovascular morbidity in Italy. A national analysis. Eur. J. Prev. Cardiol. 2020, zwaa084, ISBN 1700018000. [CrossRef] [PubMed]

19. National Institute of Statistics (ISTAT). Rapporto sul Territorio 2020. 2020. Available online: https://www.istat.it/it/archivio/24 0989 (accessed on 10 October 2021).

20. U.S. EPA. Integrated Review Plan for the National Ambient Air Quality Standards for Particulate Matter; U.S. Environmental Protection Agency: Washington, DC, USA, 2016.

21. Di, Q.; Dai, L.; Wang, Y.; Zanobetti, A.; Choirat, C.; Schwartz, J.D.; Dominici, F. Association of Short-term Exposure to Air Pollution With Mortality in Older Adults. JAMA 2017, 318, 2446. [CrossRef] [PubMed]

22. Dee, D.P.; Uppala, S.M.; Simmons, A.J.; Berrisford, P.; Poli, P.; Kobayashi, S.; Andrae, U.; Balmaseda, M.A.; Balsamo, G.; Bauer, P.; et al. The ERA-Interim reanalysis: Configuration and performance of the data assimilation system. Q. J. R. Meteorol. Soc. 2011, 137, 553-597. [CrossRef]

23. Steadman, R.G. The Assessment of Sultriness. Part I: A Temperature-Humidity Index Based on Human Physiology and Clothing Science. J. Appl. Meteorol. 1979, 18, 861-873. [CrossRef]

24. O'Neill, M.S.; Zanobetti, A.; Schwartz, J. Modifiers of the temperature and mortality association in seven US cities. Am. J. Epidemiol. 2003, 157, 1074-1082. [CrossRef]

25. European Commission; FAO; OECD; World Bank. Applying the Degree of Urbanisation. 2020. Available online: https://ec. europa.eu/eurostat/documents/10186/11395216/DEGURBA-manual.pdf/3a6bab6a-3fb1-4261-ad5b-e604cb67dc0d (accessed on 10 October 2021).

26. Gasparrini, A.; Armstrong, B.; Kenward, M.G. Multivariate meta-analysis for non-linear and other multi-parameter associations. Stat. Med. 2012, 31, 3821-3839. [CrossRef] [PubMed]

27. Janssen, N.; Fischer, P.; Marra, M.; Ameling, C.; Cassee, F.R. Short-term effects of $\mathrm{PM}_{2.5}, \mathrm{PM}_{10}$ and $\mathrm{PM}_{2.5-10}$ on daily mortality in the Netherlands. Sci. Total Environ. 2013, 463-464, 20-26. [CrossRef]

28. Kim, K.H.; Kabir, E.; Kabir, S. A review on the human health impact of airborne particulate matter. Environ. Int. 2015, 74, 136-143. [CrossRef]

29. Li, W.; Wilker, E.H.; Dorans, K.S.; Rice, M.B.; Schwartz, J.; Coull, B.A.; Koutrakis, P.; Gold, D.R.; Keaney, J.F.; Lin, H.; et al. Short-Term Exposure to Air Pollution and Biomarkers of Oxidative Stress: The Framingham Heart Study. J. Am. Heart Assoc. 2016, 5, 1-8. [CrossRef] [PubMed]

30. Rich, D.Q.; Kipen, H.M.; Huang, W.; Wang, G.; Wang, Y.; Zhu, P.; Ohman-Strickland, P.; Hu, M.; Philipp, C.; Diehl, S.R.; et al. Association Between Changes in Air Pollution Levels During the Beijing Olympics and Biomarkers of Inflammation and Thrombosis in Healthy Young Adults. JAMA 2012, 307, 1-7. [CrossRef] [PubMed] 
31. Rückerl, R.; Hampel, R.; Breitner, S.; Cyrys, J.; Kraus, U.; Carter, J.; Dailey, L.; Devlin, R.B.; Diaz-Sanchez, D.; Koenig, W.; et al. Associations between ambient air pollution and blood markers of inflammation and coagulation/fibrinolysis in susceptible populations. Environ. Int. 2014, 70, 32-49. [CrossRef] [PubMed]

32. Li, H.; Cai, J.; Chen, R.; Zhao, Z.; Ying, Z.; Wang, L.; Chen, J.; Hao, K.; Kinney, P.L.; Chen, H.; et al. Particulate matter exposure and stress hormone levels: A randomized, double-blind, crossover trial of air purification. Circulation 2017, 136, 618-627. [CrossRef] [PubMed]

33. Bateson, T.F.; Schwartz, J. Who is Sensitive to the Effects of Particulate Air Pollution on Mortality ? A Case-Crossover Analysis of Effect Modifiers. Epidemiology 2004, 15, 143-149. [CrossRef] [PubMed]

34. Sunyer, J.; Schwartz, J.; Tobías, A.; Macfarlane, D.; Garcia, J.; Antó, J.M. Patients with chronic obstructive pulmonary disease are at increased risk of death associated with urban particle air pollution: A case-crossover analysis. Am. J. Epidemiol. 2000, 151, 50-56. [CrossRef]

35. Hong, Y.C.; Lee, J.T.; Kim, H.; Ha, E.H.; Schwartz, J.; Christiani, D.C. Effects of air pollutants on acute stroke mortality. Environ. Health Perspect. 2002, 110, 187-191. [CrossRef]

36. Rumley, A.; Emberson, J.R.; Wannamethee, S.G.; Lennon, L.; Whincup, P.H.; Lowe, G.D.O. Effects of older age on fibrin D-dimer, C-reactive protein, and other hemostatic and inflammatory variables in men aged 60-79 years. J. Thromb. Haemost. 2006, 4, 982-987. [CrossRef]

37. Quarck, R.; Nawrot, T.; Meyns, B.; Delcroix, M. C-Reactive Protein. A New Predictor of Adverse Outcome in Pulmonary Arterial Hypertension. J. Am. Coll. Cardiol. 2009, 53, 1211-1218. [CrossRef] [PubMed]

38. Yunginger, J.W.; Reed, C.E.; O'Connell, E.J.; Melton, L.J.; O'Fallon, W.M.; Silverstein, M.D. A Community-based Study of the Epidemiology of Asthma: Incidence Rates, 1964-1983. Am. Rev. Respir. Dis. 1992, 146, 888-894. [CrossRef] [PubMed]

39. Clougherty, J.E. A growing role for gender analysis in air pollution epidemiology. Environ. Health Perspect. 2010, 118, 167-176. [CrossRef] [PubMed]

40. Samoli, E.; Analitis, A.; Touloumi, G.; Schwartz, J.; Anderson, H.R.; Sunyer, J.; Bisanti, L.; Zmirou, D.; Vonk, J.M.; Pekkanen, J.; et al. Estimating the Exposure-Response Relationships between Particulate Matter and Mortality within the APHEA Multicity Project. Environ. Health Perspect. 2005, 88, 88-95. [CrossRef]

41. Schwartz, J.; Laden, F.; Zanobetti, A. The concentration-response relation between $\mathrm{PM}_{2.5}$ and daily deaths. Environ. Health Perspect. 2002, 10, 1025-1029. [CrossRef]

42. Hanigan, I.C.; Rolfe, M.I.; Knibbs, L.D.; Salimi, F.; Cowie, C.T.; Heyworth, J.; Marks, G.B.; Guo, Y.; Cope, M.; Bauman, A.; et al. All-cause mortality and long-term exposure to low level air pollution in the ' 45 and up study' cohort, Sydney, Australia, 2006-2015. Environ. Int. 2019, 126, 762-770. [CrossRef] [PubMed]

43. Petrelli, A.; Di Napoli, A.; Sebastiani, G.; Rossi, A.; Giorgi Rossi, P.; Demuru, E.; Costa, G.; Zengarini, N.; Alicandro, G.; Marchetti, S.; et al. Italian Atlas of mortality inequalities by education level. Epidemiol. Prev. 2019, 43, 1-120. [CrossRef] [PubMed] 